\title{
Originals
}

\section{Prospective analysis of islet cell antibodies in children with Type 1 (insulin-dependent) diabetes}

\author{
H. Kolb ${ }^{1}$, K. Danneh1 ${ }^{1}$, D. Grüneklee ${ }^{1}$, J.Zielasek ${ }^{1}$, J. Bertrams ${ }^{2}$, A. Hübinger ${ }^{1}$ and F. A. Gries ${ }^{1}$ \\ ${ }^{1}$ Diabetes Research Institute, University of Düsseldorf, Düsseldorf and ${ }^{2}$ Elisabeth Hospital, Essen, FRG
}

\begin{abstract}
Summary. The prevalence of islet cell antibodies in children with Type 1 (insulin-dependent) diabetes was determined in a cohort of 678 children. The natural course of islet cell antibodies was followed in 375 children at 1 year, 252 and 135 children after 2 and 3 years respectively. Islet cell antibodies were determined by indirect immunofluorescence on cryostat sections of human pancreas. At diagnosis of diabetes $85 \%$ of the children had detectable islet cell antibodies (mean titre 10.4). After 3 years $62 \%$ of the children were still islet cell antibody positive (mean titre 2.9 ) indicating a greater persistence of islet cell antibodies than described in earlier studies. In this large cohort a significant correlation between
\end{abstract}

islet cell antibody prevalence or persistence and sex, age or HLA-DR type was not observed except for a faster loss of islet cell antibodies in very young boys and in patients lacking HLA-DR types 3 and 4. Complement fixing islet cell antibodies correlated with high titre islet cell antibodies. Greater persistence of islet cell antibodies was seen for cases with high antibody titre and in children with diagnosis of diabetes during the first half of the year.

Key words: Type 1 (insulin-dependent) diabetes, islet cell antibody, seasonal efects, epidemiology, HLA-dependence.
The first demonstration of islet cell antibodies (ICA) in 1974 has been followed by considerable research activity in this field [1-4]. Up to now, sufficient knowledge on the antigenic determinants on or in islet cells has been lacking; and antibody specifities cannot be clearly distinguished. The correlation of ICA with patient's age, sex, HLA type and season has been studied in cross-sectional and some small prospective studies [4-15]. We therefore, have-performed a study of ICA in 678 children (1-15 years of age) with recent onset Type 1 (insulin-dependent) diabetes. A fraction of the patients could be followed for 1-3 years. With this large cohort a number of hypotheses derived from earlier studies were tested. In particular, the HLA dependence of ICA production and the loss of ICA during the first two years after diabetes onset were examined.

\section{Subjects and methods}

In the Federal Republic of Germany the majority of children's hospitals were approached for cooperation. Diabetes centers were avoided because of the possibility of non-representative patient cohorts in these institutions. A total of 351 paediatricians kindly agreed to participate in the study. During 1977-1980, 678 children aged 1-15 (mean 9.8) years (female, 49\%) entered the study. All children whose parents and treating physicians agreed to participate in the study were recruited. Other selection criteria were not used. The initial blood sample was drawn within 8 weeks after diagnosis of Type 1 diabetes; further samples were obtained at $12,24,36$ months.

ICA were determined using the conventional immunofluorescence test of cryostat sections of human pancreas from cadaver kidney donors, blood group 0 , as described previously $[10,15]$. Since 1977 three different pancreatic specimen $(A, B, C)$ have been used in ICA assays. Comparative studies using a panel of 50 sera with ICA titres between 1 and 64 ensured that the three different tissues gave results differing no more than by one titrestep (two-fold dilution) in ICA titres. In addition, sera from 200 blood donors were tested on each of the pancreata. (The latter sera were kindly provided by Dr. W. Luboldt, Blood Transfusion Service, University of Essen.) Three sera were positive (undiluted only) on pancreas A, one on pancreas $B$ and none on pancreas C. Finally, standardisation was achieved by running each ICA test with a negative control plus an ICA positive serum used at endpoint dilution plus one titrestep less diluted to assess day to day variation. In about $6 \%$ of cases the negative control was read as weakly positive. Only sera giving a stronger signal were regarded as positive. Patient sera determined as weakly positive in such tests were retested. The positive control was always read as positive when tested 1 titrestep above endpoint dilution and read as positive at endpoint dilution in $82 \%$ of cases. Our ICA assay was compared with that of other laboratories by analysis of coded serum samples in 1985 [First International Workshop on ICA Standardisation, (16)]. For the majority of laboratories including ours linearly increasing standard curves were established. The results were in the expected order based on assigned arbitrary values. Of pancreata $B$ and $C$, reserve pieces stored in liquid nitrogen were used to 


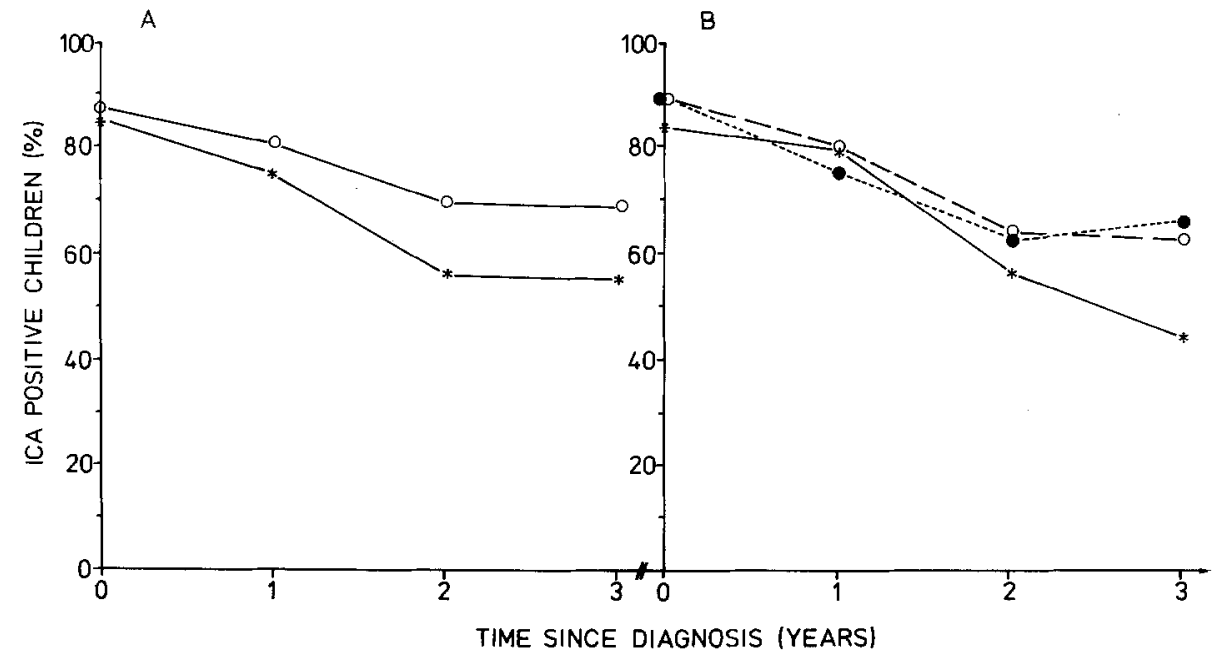

Fig. 1. A Islet cell antibody (ICA) prevalence in female $(O)$ and male $(*)$ children. At onset samples from 329 females and 349 males were tested, $n=183$ and 192 after one year, $n=123$ and 129 after two years, $n=65$ and 70 after three years. The difference in ICA prevalence between female and male children is not significant at 2 years $(p=0.13)$ or three years $(p=0.30)$. B ICA prevalence in children aged 1-5 $\left(*_{-}^{*}\right), 6-10\left(0-0_{-}\right)$and $11-15(0 \ldots$. years. At onset samples from 120 children 1-5 years, 264 children 6-10 years, 290 children $11-15$ years were tested, $n=54,150$ and 171 after one year; $n=35$, 96 and 121 after two years; $n=20,55$ and 60 after three years. The difference in ICA prevalence between age groups 1- 5 years and $11-15$ years is not significant at 2 years $(p=0.546)$ or 3 years $(p=0.08)$
Table 1. Prospective analysis of islet cell antibody (ICA) titres by sex or age

\begin{tabular}{|c|c|c|c|c|}
\hline \multirow[t]{2}{*}{ Subgroup } & \multicolumn{4}{|c|}{ Mean ICA titre ${ }^{a} \mathrm{GM} \times \mathrm{SD}^{ \pm 1}$} \\
\hline & At onset & At 1 year & At 2 years & At 3 years \\
\hline Female & $\begin{array}{l}11.9 \times 3.2^{ \pm 1} \\
(n=149)\end{array}$ & $\begin{array}{l}6.9 \times 3.3^{ \pm 1} \\
(n=118)\end{array}$ & $\begin{array}{l}5.2 \times 3.5^{ \pm 1} \\
(n=61)\end{array}$ & $\begin{array}{l}2.3 \times 2.2^{ \pm 1} \\
(n=27)\end{array}$ \\
\hline Male & $\begin{array}{l}8.8 \times 3.4^{ \pm 1} \\
(n=148)\end{array}$ & $\begin{array}{l}5.2 \times 3.2^{ \pm 1} \\
(n=109)\end{array}$ & $\begin{array}{l}5.0 \times 3.7^{ \pm 1} \\
(n=40)\end{array}$ & $\begin{array}{l}3.4 \times 2.7^{ \pm 1} \\
(n=20)\end{array}$ \\
\hline $\begin{array}{l}\text { Age } \\
1-5\end{array}$ & $\begin{array}{l}12.1 \times 3.2^{ \pm 1} \\
(n=40)\end{array}$ & $\begin{array}{l}5.8 \times 2.8^{ \pm 1} \\
(n=33)\end{array}$ & $\begin{array}{l}5.3 \times 3.9^{ \pm 1} \\
(n=10)\end{array}$ & $\begin{array}{l}1.7 \times 1.9^{ \pm 1} \\
(n=4)\end{array}$ \\
\hline $\begin{array}{l}\text { Age } \\
6-10\end{array}$ & $\begin{array}{l}9.9 \times 3.2^{ \pm 1} \\
(n=120)\end{array}$ & $\begin{array}{l}5.8 \times 3.3^{ \pm 1} \\
(n=95)\end{array}$ & $\begin{array}{l}5.1 \times 3.2^{ \pm 1} \\
(n=40)\end{array}$ & $\begin{array}{l}3.0 \times 2.4^{ \pm 1} \\
(n=20)\end{array}$ \\
\hline $\begin{array}{l}\text { Age } \\
11-15\end{array}$ & $\begin{array}{l}10.0 \times 3.6^{ \pm 1} \\
(n=137)\end{array}$ & $\begin{array}{l}6.3 \times 3.3^{ \pm 1} \\
(n=99)\end{array}$ & $\begin{array}{l}5.1 \times 3.9^{ \pm 1} \\
(n=51)\end{array}$ & $\begin{array}{l}2.7 \times 2.5^{ \pm 1} \\
(n=23)\end{array}$ \\
\hline
\end{tabular}

${ }^{\text {a }}$ Numbers give the mean antibody titre for ICA positive children. Differences in titres between subgroups were not significant. GM geometric mean; SD - standard deviation factor

relate ICA titres given here to Juvenile Diabetes Foundation (JDF) units defined by a standard serum distributed on the occasion of the Third International Workshop on ICA Standardisation 1987. Coded slides were read by two investigators. Ten JDF units were found equivalent to an ICA titre of 8 plus/minus one titrestep.

The majority of sera from the 678 children were tested in 1983 and 1984 on a single pancreatic tissue (pancreas C). In addition, we excluded possible errors from year to year variation by running in parallel in the same test serum samples from a given individual at diabetes onset, after one, two and three years. Individual serum samples were divided into several portions before freezing in order to minimise repeated thawing and freezing. Only in cases where extensive retesting was done did samples have to be thawed more than twice. As a control, 20 sera were thawed and refrozen 6 times during 3 months and thereafter compared with 20 parallel samples which had continuously been kept frozen. The average ICA titre decrease due to repeated thawing and freezing was $40 \%$, i.e. less than one titrestep $(50 \%)$. ICA titres were determined for all children with known HLA type, provided that sufficient serum was available, plus from a random selection of other children. HLA typing was performed using the standard microlymphocytotoxicity technique [17] and a set of 200 highly selected antisera. Non-T cells were enriched by nylon wool columns for HLA-DR typing. The following antigens could be identified: HLA-A1, A2, A3, A11, A23, A24, A25, A26,
A28, A29, A30, A31, A32, Aw33; HLA-B7, B8, B13, B14, B18, B27, B35, B37, B38, B39; Bw41, B44, B45, Bw47, Bw49, Bw50, B51, B52, Bw53, Bw55, Bw57, Bw58, Bw60, Bw61, Bw62, Bw63; HLA-Cw1, Cw2, Cw3, Cw4, Cw5, Cw6, Cw7; HLA-DR1, DR2, DR3, DR4, DR5, DRw6, DR7, DRw8.

\section{Statistical analysis}

The ICA titres show a log gaussian distribution. Therefore, the data are presented as geometrical mean: $\mathrm{GM} \times \mathrm{SD}^{ \pm 1}(\mathrm{GM}=$ geometric mean; $\mathrm{SD}=$ standard deviation factor). All other data are presented as relative frequencies, stated as percent. The statistical comparison of ICA titres between groups was performed (after adjustement to pre-values) using one factor analysis of variance. Relative frequencies between groups (also with respect to the pre-values) were tested with chi-square test for $\mathbf{k} \times 2$ tables. The level of statistical significance was fixed for all statistical tests uniformly to $p=0.05$ (twosided).

\section{Results}

Serum samples were obtained from 678 children within 8 weeks after diagnosis of Type 1 diabetes. Around $86 \%$ of sera from both females and males contained detectable amounts of ICA; the mean titre in females was 11.9 and in males 8.8 (Table 1). Decrease in ICA prevalence was minimal after one year; even after two and three years the majority of children tested remained ICA positive (Fig. 1A), although average titres had declined by a factor of 2-4 (Table 1).

An analysis of the same data by age shows a quite similar prevalence and persistence of ICA in the $3 \mathrm{sub}$ groups (Fig. 1 B and Table 1). Further analysis of the 1-5 years-of-age subgroup revealed that a faster loss of ICA positivity is seen for the male subgroup, 1-5 yearold females do not differ significantly from the elder children (Fig. 1 B and 2, $p=0.019$ ).

All children whose parents and treating physicians agreed were HLA typed, also with respect to the HLADR region. The correlation between HLA-DR type and ICA prevalence and titre is shown in Fig. $3 \mathrm{~A}$. The 


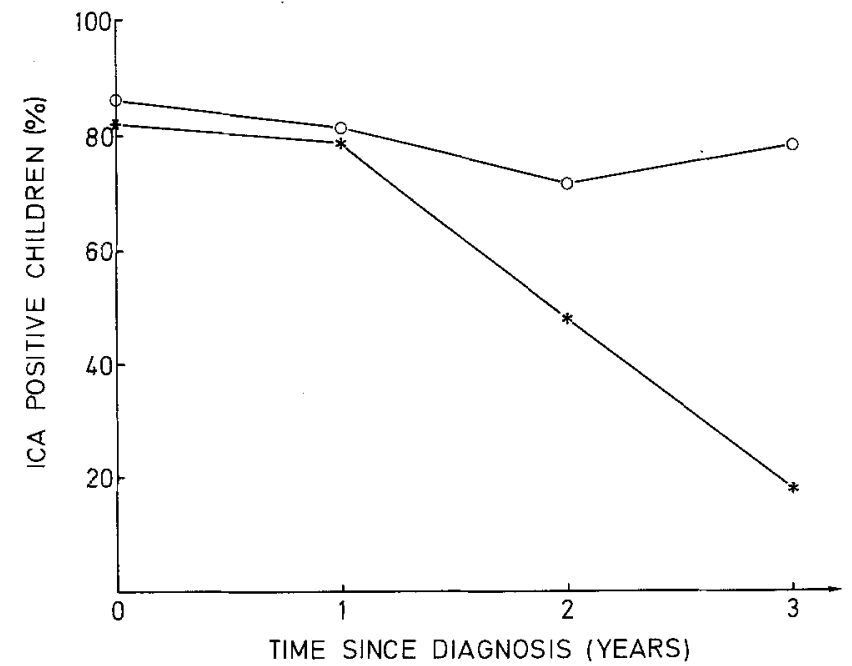

Fig. 2. ICA prevalence in female $(O)$ and male $(*)$ children aged 1-5 years. At onset samples from 56 females and 64 males were tested, $n=26$ and 28 after one year, $n=14$ and 21 after two years, $n=9$ and 11 after three years. Mean titres were (female) $17.4 \times 2.5^{ \pm 1}$, $6.6 \times 2.9^{ \pm 1}, 5.7 \times 4.2^{ \pm 1}, 1.7 \times 1.9^{ \pm 1}$ and (male) $9.3 \times 3.5^{ \pm 1}, 5.2 \times 2.8^{ \pm 1}$, $4.8 \times 4.2^{ \pm 1}\left(\mathrm{GM} \times \mathrm{SD}^{ \pm 1}\right)$. The difference in ICA prevalence between female and male children is not significant at 2 years $(p=0.382)$ and significant at 3 years $(p=0.019)$

three major cohorts characterised by DR3/x, DR4/x and DR3/4 do not show large differences. Mean titres do not reveal large differences either (Table 2). The small subgroup of children with neither DR3 nor DR4 shows a lower prevalence of ICA at diabetes onset and also decreased persistence (versus HLA-DR3/x, $p=0.046$, Fig. 3 A). DRx $/ \mathrm{x}$ types consisted of DR1 (33.3\%), DR7 (22.2\%), DR6 (14.8\%), DR5 (11.1\%), DR8 (11.1\%) and DR2 (7.4\%).

A second analysis of the correlation between HLADR type and ICA prevalence/persistence was performed by considering only cases with an initial titre of $\geq 8$. After three years, $17.4 \%$ of sera from children with $\mathrm{DR} 3 / \mathrm{x}$ are still $\geq 8$ in titre whereas it is $2.7 \%$ in children with $D R 4 / x$ (difference not significant). Values for HLA-DR3/4 lie in between (Fig. 3B).

A clear correlation was observed between ICA persistence and titre at onset (Fig. 4); i.e. children with initial high titre ICA showed greater antibody persistence than the ones with initial lower ICA titre $(p=0.001)$.

In 99 children ICA negative at onset, and in 90 children who became ICA negative during the course of the study serum samples were tested for reappearance of ICA. In all cases where an ICA negative child had become positive later on, all serum samples were run again in the same test. Our final result is that in 18 cases ICA (re)appeared in children who had an earlier ICA negative sample (Table 3). In none of these cases ICA titres rose above 4 .

In looking for a further fluctuation of ICA titres we similarly reanalysed all cases where ICA titres had risen during the course of the study. We did not observe a single case with an ICA titre increase by more than

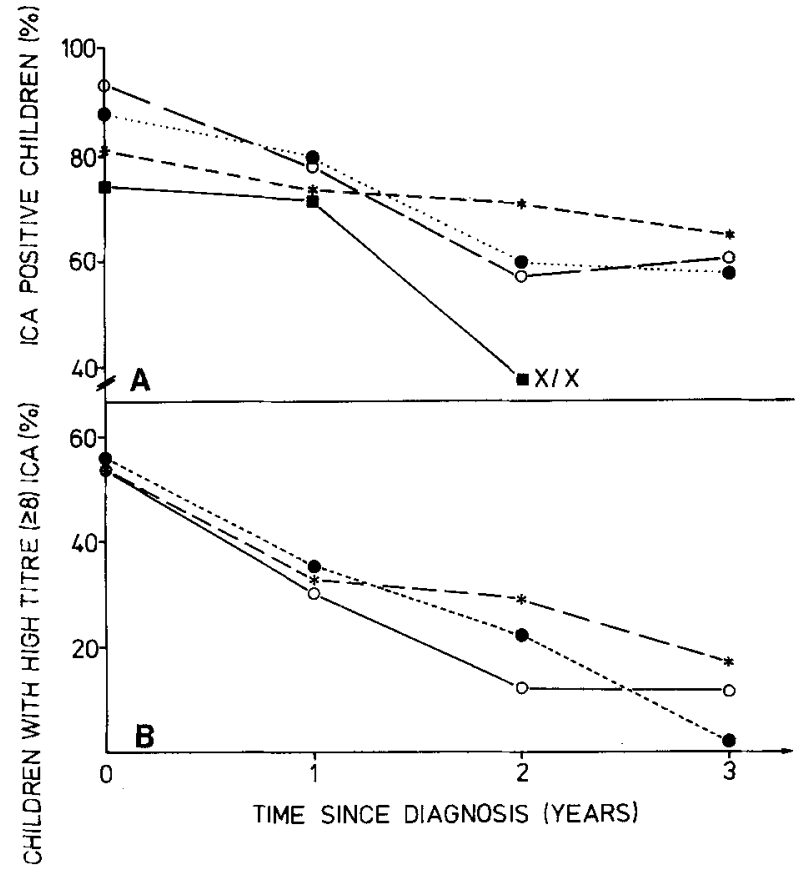

Fig. 3. A Correlation between ICA prevalence and persistence and HLA-DR types. At onset samples from 295 children were studied (DR3/x:53 (*-..*), DR4/x:120 (…e), DR3/4:106 (O- - O), $\mathrm{DRx} / \mathrm{x}: 16(-))$, after one year from 217 children $(35,89,82$, 11), after two years from 172 children $(28,71,65,8)$, after three years from 103 children $(25,45,33)$. The difference in ICA prevalence between subgroups $D R 4 / x$ and $D R 3 / x$ is not significant at 2 years $(p=0.086)$ or three years $(p=0.355)$, the difference between $\mathrm{DRx} / \mathrm{x}$ and $\mathrm{DR} 3 / \mathrm{x}$ is significant at 2 years $(p=0.046)$. B Correlation between persistence of high titre ICA and HLA-DR types. At onset samples from 218 childrén were studied (DR3/x:43 (*_...*), DR4/x:93 ( … D ) DR3/4:82 ( $\mathrm{O}-\mathrm{O})$, after one year from 187 children $(31,79,77)$, after two years from 144 children $(22,65$, $57)$, after three years from 88 children $(23,37,28)$. The difference in ICA prevalence between subgroups DR3/4 and DR3/x at 2 years is not significant $(p=0.230)$, the difference between $\mathrm{DR} 4 / \mathrm{x}$ and $\mathrm{DR} 3 / \mathrm{x}$ is not significant at 3 years $(p=0.289)$

Table 2. Prospective analysis of ICA titres by HLA-DR type

\begin{tabular}{lllll}
\hline $\begin{array}{l}\text { HLA-DR } \\
\text { type }\end{array}$ & \multicolumn{4}{l}{ Mean ICA-titre $\left(\mathrm{GM} \times \mathrm{SD}^{ \pm 1}\right)$} \\
\cline { 2 - 5 } & At onset & At 1 year & At 2 years & At 3 years \\
\hline $3 / \mathrm{x}$ & $10.5 \times 2.9^{ \pm 1}$ & $6.4 \times 3.2^{ \pm 1}$ & $5.4 \times 3.8^{ \pm 1}$ & $3.6 \times 2.6^{ \pm 1}$ \\
$(\mathrm{x} \neq 4)$ & $(n=33)$ & $(n=22)$ & $(n=14)$ & $(n=14)$ \\
$4 / \mathrm{x}$ & $10.8 \times 3.4^{ \pm 1}$ & $5.6 \times 3.6^{ \pm 1}$ & $4.9 \times 3.9^{ \pm 1}$ & $2.7 \times 1.9^{ \pm 1}$ \\
$(\mathrm{x} \neq 3)$ & $(n=79)$ & $(n=61)$ & $(n=36)$ & $(n=18)$ \\
$3 / 4$ & $8.5 \times 4.0^{ \pm 1}$ & $4.9 \times 3.3^{ \pm 1}$ & $3.6 \times 3.0^{ \pm 1}$ & $2.1 \times 2.8^{ \pm 1}$ \\
& $(n=75)$ & $(n=60)$ & $(n=30)$ & $(n=15)$ \\
$\mathrm{x} / \mathrm{x}$ & $5.4 \times 4.0^{ \pm 1}$ & $5.7 \times 1.8^{ \pm 1}$ & $2.0 \times 2.0^{ \pm 1}$ & - \\
& $(n=9)$ & $(n=6)$ & $(n=3)$ & - \\
\hline$p$ & - & 0.347 & 0.253 & 0.192 \\
\hline
\end{tabular}

Numbers give the mean antibody titre for ICA positive children, the percentage of ICA positive cases is given in Figure 3

2 titresteps. In 278 ICA positive sera the relationship between ICA and complement fixing (CF-) ICA was studied. As shown in Table 4, a correlation exists be- 


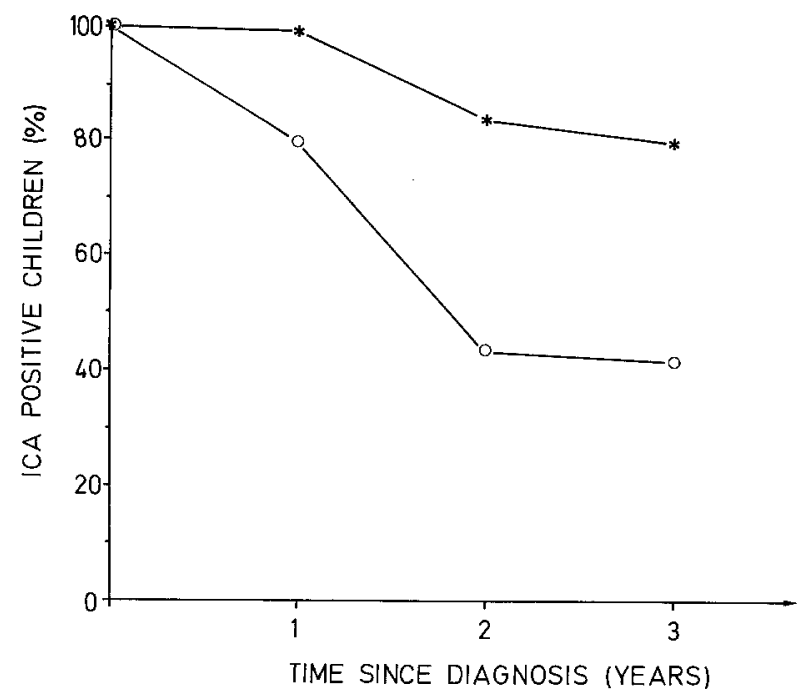

Fig.4. Better persistence of ICA in children with higher $(\geq 8)(*)$ antibody titre at onset. Number of children studied at onset was 297. Of these 199 had an ICA titre $\geq 8$ and 98 an ICA titre between 1-4 (O). Follow-up was possible in $241,169,95$ children after one, two, three years. The difference in ICA prevalence between the 2 subgroups is significant at 2 years $\left(p=2.97 \times 10^{-8}\right)$ and 3 years $(p=0.00042)$

Table 3. Fluctuation of ICA

\begin{tabular}{lll}
\hline $\begin{array}{l}\text { ICA negative or } \\
\text { disappearance at }\end{array}$ & ICA (re)appearance at & $\begin{array}{l}\text { No. cases } \\
\text { observed/ } \\
\text { No. analysed }\end{array}$ \\
\hline Diabetes onset & 1 year & $5 / 51(9.8 \%)$ \\
Diabetes onset & 2 years & $4 / 33(12.1 \%)$ \\
Diabetes onset & 3 years & $1 / 15(6.7 \%)$ \\
1 year & 2 years & $6 / 42(14.3 \%)$ \\
1 year & 3 years & $1 / 18(5.6 \%)$ \\
2 years & 3 years & $1 / 30(3.3 \%)$ \\
\hline
\end{tabular}

Table 4. Correlation between ICA titre and complement fixing ability

\begin{tabular}{rcl}
\hline ICA-titre & $\begin{array}{l}\text { CF-ICA } \\
\text { positive }\end{array}$ & $\begin{array}{l}\text { Cases } \\
\text { observed }\end{array}$ \\
\hline 1 & $0 \%$ & $(n=17)$ \\
2 & $15 \%$ & $(n=26)$ \\
4 & $37 \%$ & $(n=51)$ \\
8 & $62 \%$ & $(n=61)$ \\
16 & $65 \%$ & $(n=37)$ \\
32 & $82 \%$ & $(n=55)$ \\
64 & $92 \%$ & $(n=26)$ \\
$\geq 128$ & $100 \%$ & $(n=5)$ \\
\hline$p$ & $<0.0001$ & \\
\hline
\end{tabular}

tween high titre ICA and complement fixing ability $(p<0.0001)$. Still, some of the low ICA titre sera were CF-ICA positive. A similar number of high ICA titre sera did not contain CF-ICA.

In a final series of calculations we searched for an association between season of diabetes diagnosis and
ICA status. As shown in Figure 5, the persistence of ICA is higher in children with diagnosis of diabetes during January-June when compared to months July-December $(p=0.0022)$.

The prospective analysis of ICA prevalence and titres could be influenced by the decreasing number of children available for retesting at 1,2 and 3 years. For this reason it was determined whether the fraction of children studied at 1,2 or 3 years had significantly different ICA characteristics at entry than described for the total cohort. This was not the case.

\section{Discussion}

Our prospective analysis of ICA in children with recently diagnosed Type 1 diabetes shows substantial persistence of ICA production over the first three years. Prevalence of ICA was $86 \%$ at diabetes diagnosis and still $62 \%$ at three years. Most data reported so far have indicated a much more rapid loss of ICA with less than $40 \%$ of patients positive for ICA after 1-2 years [5, 7, 8, 11-13]. However, a few small studies indicated persistence of ICA similar to our observations $[9,10]$. The reason for this discrepancy is not clear. The patient population studied is highly unselected since participating hospitals were distributed throughout the Federal Republic of Germany, and entry in the study continued during 4 consecutive years (1977-1980) without restriction to a specific season. Differences in age at diabetes onset do not seem to play a role since other studies also included children. A more probable explanation may be differences in test sensitivity. The introduction of standard ICA units will allow better comparison of ICA data.

Although some heterogeneity in the disease process depending on age, sex and HLA type can be expected, only minor effects of these parameters on ICA titre and prevalence were noted. One special observation is that boys tend to loose ICA faster, especially in the young age group (1-5 years). Another interesting point is the lower persistence of ICA in patients with HLA$\mathrm{DRx} / \mathrm{x}$. Unfortunately, little is known on the natural course of diabetes in this subgroup.

The lack of HLA dependence of ICA production reported here contrasts with earlier findings of an increased ICA prevalence in patients with HLA-B8 or -DR3 found in smaller cohorts [18, 19, reviewed in 11] Our data confirm a similar report by Barbosa et al. [11]. Do ICA "fluctuate"? In our cohort 9.5\% of ICA negative children went on to develop ICA later on. Experimental artefacts were excluded since negative and positive sera were tested the same day. In all these cases only low titre ICA were measured. In ICA positive children titre increases greater than 4-fold were never observed. Our conclusion is that ICA titres may "fluctuate" by two titresteps. Low ICA titres thereby may transiently drop below the detection limit (turning 


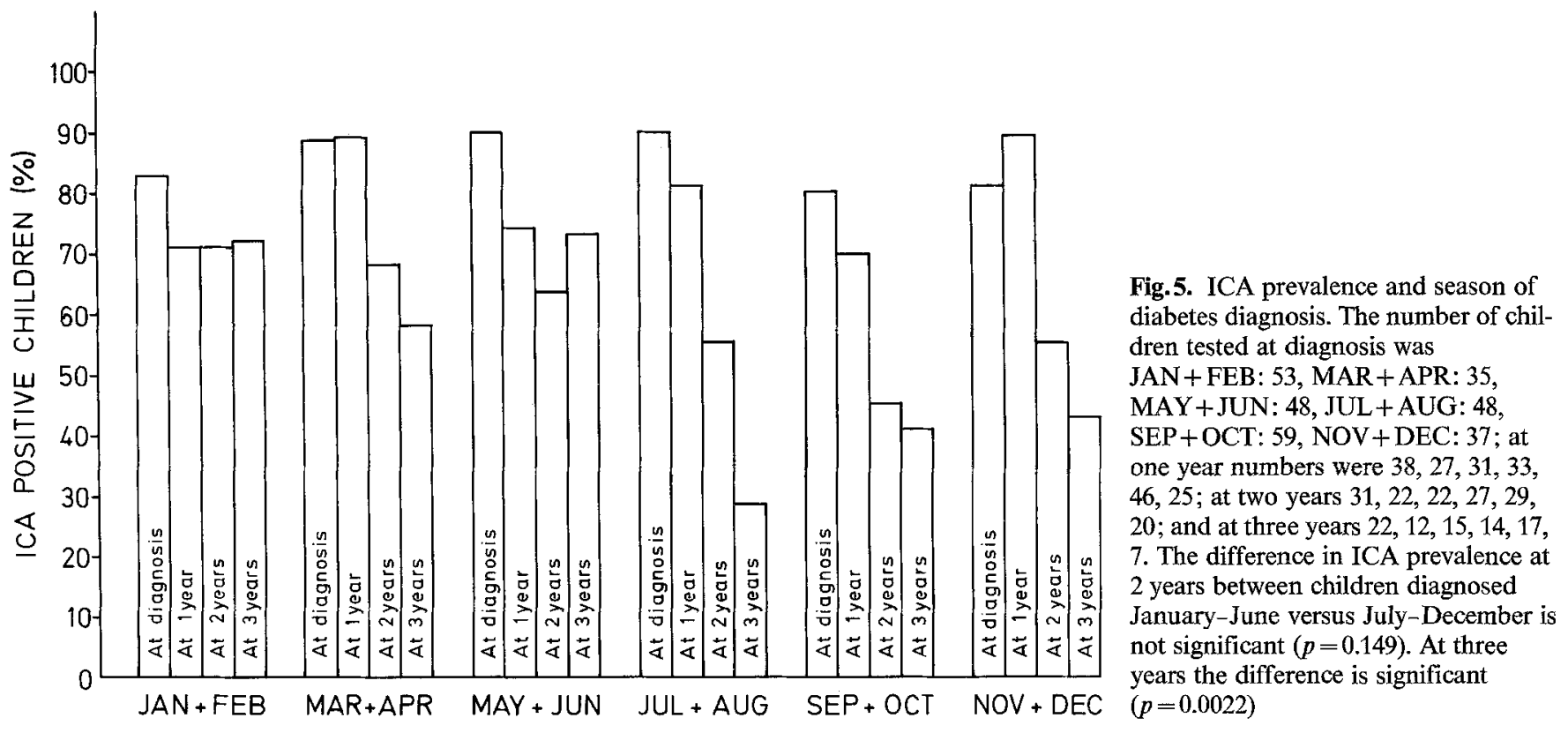

"negative") and slightly increase (turning "positive") later on. Thus, it is only the low ICA titre which may turn negative and reappear later on. Controversial reports from different laboratories may be due to analysis of cases with high or low ICA titre respectively [20-22]. The fluctuation of ICA in non diabetic individuals is presently being analysed.

Since patients were recruited to the study without prior selection during all seasons of several years (1977-1980) we had the opportunity to search for a correlation between season of diabetes diagnosis and ICA prevalence. In our cohort, greater persistence of ICA is seen for children with diagnosis of diabetes during the first half of the year. The interval between first classical symptoms and diagnosis may be 1-3 months, so that for children with greater ICA persistence the onset of the disease probably is during autumn and winter.

Acknowledgements. The authors are grateful to Professor H. Müntefering and to Hoechst AG, Frankfurt, FRG, for invaluable help in initiation and performance of the study. We thank all physicians who participated in the study. We thank K. Roßbach, B. Schmidt, I. Barberena and K.Quinkert for help with ICA- and HLA-determinations and A. Wachowiak and M.Solomon for documentation of study data. This work was supported by the Deutsche Forschungsgemeinschaft, Sonderforschungsbereich 113 , by the Minister für Forschung und Wissenschaft des Landes Nordrhein-Westfalen and by the Bundesminister für Jugend, Familie und Gesundheit.

\section{References}

1. Bottazzo GF, Florin-Christensen A, Doniach D (1974) Islet-cell antibodies in diabetes mellitus with autoimmune polyendocrine deficiencies. Lancet II: 1279-1282

2. MacCuish AC, Barnes EW, Irvine WJ, Duncan LJP (1974) Antibodies to pancreatic islet-cells in insulin-dependent diabetes with coexistent autoimmune disease. Lancet II: 1529-1531
3. Lendrum R, Walker G, Gamble DR (1975) Islet-cell antibodies in juvenile diabetes mellitus of recent onset. Lancet I: 880-883

4. Drell DW, Notkins AL (1987) Multiple immunological abnormalities in patients with Type 1 (insulin-dependent) diabetes mellitus. Diabetologia 30: 132-143

5. Del Prete GF, Betterle C, Padovan D, Erle G, Toffolo A, Bersahi $G$ (1977) Incidence and significance of islet-cell autoantibodies in different types of diabetes mellitus. Diabetes 26: 909-914

6. Gorsuch AN, Lister J, Dean BM, Spencer KM, McNally JM, Bottazzo GF, Cudworth AG (1981) Evidence for a long prediabetic period in type 1 (insulin-dependent) diabetes mellitus. Lancet II: $1363-1365$

7. Irvine WJ, McCallum CJ, Gray RS, Casmbell CJ, Duncan LJP, Farquhar JW, Vaughan H, Morris PJ (1977) Pancreatic islet-cell antibodies in diabetes mellitus correlated with the duration and type of diabetes, coexistent autoimmune disease, and HLA type. Diabetes 26: 138-147

8. Riley WJ, Neufeld M, MacLaren NK (1980) Complement-fixing islet-cell antibodies: a separate species? Lancet I: 1133

9. Betterle C, Caretto A, Tiengo A, Trevisan A (1980) Complementfixing islet-cell antibodies in type 1 diabetes and in susceptible patients with autoimmune diseases. Lancet I: 1418-1419

10. Kolb H, Stroheker M, Biener J, Grüneklee $D$, Müntefering $H$, Gries FA (1980) Analysis of the persistence of islet cell antibodies and islet cell type-specific antibodies in type 1 diabetic children. Autoimmune aspect of endocrine disorders. In: Pinchera A, Doniach D, Fenzi GF, Baschieri L (eds) Academic Press, London, pp 291-294

11. Barbosa J, Chavers B, Dunsworth T, Michael A (1982) Islet cell antibodies and histocompatibility antigens (HLA) in insulin-dependent diabetics and their first-degree relatives. Diabetes 31: $585-588$

12. Borsey DQ, DiMario U, Irvine WJ, Gray RS, Guy K, Weston J, Peutherer J, Duncan LJP (1983) Humoral immunity in type 1 diabetes mellitus: a prospective study. J Clin Lab Immunol 11: 9-15

13. Marner B, Agner T, Binder C, Lernmark A, Nerup J, MandírupPoulsen T, Walldorff S (1985) Increased reduction in fasting Cpeptide is associated with islet cell antibodies in Type 1 (insulindependent) diabetic patients. Diabetologia 28: 875-880

14. Bruining GJ, Molenaar J, Tuk CW, Lindeman J, Bruining HA, Marner B (1984) Clinical time-course and characteristics of islet cell cytoplasmatic antibodies in childhood diabetes. Diabetologia 26: $24-29$ 
15. Kolb H, Krügener G, Gries FA (1983) Islet cell autoantibodies: which method? Lancet I: 479

16. Gleichmann H, Bottazzo GF (1987) Progress towards standardisation of the cytoplasmic islet-cell antibody assay: analysis of the data presented at the first international workshop. Diabetes 36: $578-584$

17. Terasaki PI, McClelland JD (1964) Microdroplet assay of human serum cytotoxins. Nature 204: 998-1000

18. Morris PJ, Irvine WJ, Gray RS, Duncan LJP, Vaughan H, McCallum FJ, Campbell CJ, Farquhar JW (1976) HLA and pancreatic islet cell antibodies in diabetes. Lancet II: $652-653$

19. Irvine WJ, Di Mario U, Feek CM, Gray RS, Ting A, Morris PJ, Duncan LJP (1978) Autoimmunity and HLA antigens in insulindependent (type 1) diabetes. J Clin Lab Immunol 1: 107-110

20. Spencer KM, Dean BM, Tarn A, Lister J, Bottazzo GF (1984)
Fluctuating islet-cell autoimmunity in unaffected relatives of patients with insulin-dependent diabetes. Lancet I: 764-766

21. Srikanta S, Eisenbarth GS (1984) Disappearing anti-islet antibodies. Lancet I: 1676-1677

22. Riley W, MacLaren N (1984) Islet-cell antibodies are seldom transient. Lancet I: 1351-1352

Received: 13 October 1987

and in revised form: 12 February 1988

Dr. H. Kolb

Diabetes-Forschungsinstitut

Auf'm Hennekamp 65

D-4000 Düsseldorf 1

FRG 